\title{
CYP3A7*2 Allele
}

National Cancer Institute

\section{Source}

National Cancer Institute. CYP3A7*2 Allele. NCI Thesaurus. Code C46020.

Human CYP3A7*2 allele is located within $7 q 21-q 22.1$ and is approximately $30 \mathrm{~kb}$ in length. This allele, a variant form of the human CYP3A7 wild-type allele, encodes cytochrome P450 3A7*2 protein. This allele exhibits a clinically-relevant SNP (c.1226C>G) in exon 11 that results in a T409R coding change. This alteration in protein sequence increases the enzymatic activity of the cytochrome P450 3A7*2 protein. 